\title{
Economic Integration, Tax Erosion, and Decentralisation: An Empirical Analysis
}

\author{
Francesca Gastaldi ${ }^{1}$, Paolo Liberati ${ }^{2}$, Antonio Sciala ${ }^{3 *}$ \\ ${ }^{1}$ Department of Economics and Law, Sapienza Università di Roma, Rome, Italy \\ ${ }^{2}$ Department of Economics, Università Roma Tre, Rome, Italy \\ ${ }^{3}$ Department of Law, Università Roma Tre, Rome, Italy \\ Email: *antonio.sciala@uniroma3.it
}

Received July 13, 2013; revised August 15, 2013; accepted August 21, 2013

Copyright (C) 2013 Francesca Gastaldi et al. This is an open access article distributed under the Creative Commons Attribution License, which permits unrestricted use, distribution, and reproduction in any medium, provided the original work is properly cited.

\begin{abstract}
This paper addresses the issues of whether and how economic integration can affect the ability of the central governments to raise tax revenues and lead to a greater decentralisation of the public sector. To this purpose, a country-specific measure of tax erosion is derived. That is used as a determinant of the degree of fiscal federalism. We find that an increase of economic integration causes a decline of the implicit tax rates on mobile capital and the process of tax erosion positively contributes to the growth of public sector decentralisation.
\end{abstract}

Keywords: Economic Integration; Tax Erosion; Fiscal Federalism; Implicit Tax Rates; Tax Competition

\section{Introduction}

The economic literature that investigates the impact of international tax competition on public finance variables mainly suggests that economic integration may introduce constraints on national public policies (among many, $[1-3]) .{ }^{1}$ In these cases, however, the public sector is usually considered as a monolithic entity and the impact of economic integration is analysed as if states were organised on a unitary basis. On the other hand, those studies that investigate the link between decentralisation and government size rarely consider that economic integration can affect the vertical structure of the public sector, dealing with this issue as if states were closed ${ }^{2}$.

This paper tries to build a bridge between these two separate strands of literature, addressing in a unified empirical framework with the relationships among eco-

\footnotetext{
*Corresponding author.

${ }^{1}$ In what follows, we will use the terms "economic integration" and "economic openness" interchangeably, to mean a country's exposure to foreign trade and financial flows.

${ }^{2} \mathrm{~A}$ notable exception to this artificial division of interests is [4], who finds (among EU countries) that greater economic integration may be positively associated to a greater decentralisation through the increasing demand for productive local public goods that would be stimulated by economic openness. In this case, however, the level of decentralisation in each country is directly related to its degree of economic integration, which amounts to assume that two countries that exhibit the same economic openness would experiment the same constraints on public finance variables despite potentially remarkable differences in their pre-existing tax and spending levels.
}

nomic integration, national tax revenues and fiscal federalism. ${ }^{3}$ In particular, we maintain the hypothesis that economic integration can to some extent erode the size of central tax revenues and indirectly lead to a greater decentralisation of the public sector. In particular, we postulate that since economic integration may constrain the ability of the central governments to raise additional tax revenues and increase the marginal efficiency cost of taxation, those governments may have some incentives to act strategically, by shifting tax powers to lower government levels.

In order to test our argument, we develop an econometric strategy in two stages, using a sample of OECD countries. In the first stage, economic integration is used as a determinant of the level of taxation, as measured by the implicit tax rates (ITR) developed by [6] and updated by [7]. In the second stage, a measure of tax erosion given by the elasticity of ITRs with respect to economic integration is calculated and used as a determinant of the decentralisation of the public sector.

The results of our empirical analysis show that in the first stage economic integration actually affects the ability of central governments to raise tax revenues from mobile tax bases, while it does not produce comparably significant effects on other tax bases. In the second stage, our measure of tax erosion is then found to have a sig-

${ }^{3}$ For a theoretical setting in this direction, see [4], and [5]. 
nificant relationship with the degree of decentralisation, supporting the hypothesis that economic integration can be associated to a higher degree of fiscal federalism.

The paper is organised as follows. Section 2 briefly reviews the existing literature on the links between economic integration and tax revenues and between economic integration and decentralisation. The empirical strategy is presented in Section 3, while Section 4 discusses the main results of the empirical analysis. Section 5 concludes.

\section{Economic Integration, Tax Revenues, and Decentralisation}

\subsection{Economic Integration and Tax Revenues}

Whether economic integration is potentially able to affect national tax and spending policies is an open issue. ${ }^{4}$ The literature on tax competition suggests that capital taxation would be lower with greater international capital mobility, as overtaxed capital might sanction undesirable public policies by exit national borders. ${ }^{5}$

In an extreme version of this model-that has become popular as the race-to-the-bottom hypothesis-capital mobility would cause tax revenues to disappear in the attempt of governments to create favourable conditions for investments, a feature that has led many authors to define tax competition as "harmful". 6 In a milder version, governments would be "disciplined" to a more efficient use of economic resources, the reason why this outcome is also referred to as the efficiency hypothesis in the spirit of [15]. Both cases would fall into what [16] calls the capital flight hypothesis and both, in principle, would lead, in open economies, to lower optimal tax rates on mobile factors, which means that economic openness may to some extent increase the marginal efficiency cost of public funds on mobile tax bases. ${ }^{7}$

On the other hand, some authors argue that citizens in countries with a large exposure to international trade and capital flows try to demand additional public spending (the compensation hypothesis) to cushion the additional risk embodied in opening markets (e.g., unemployment or larger income volatility). ${ }^{8}$ However, this possibility must ultimately lead to a growth of taxation (and/or debt) to finance the additional supply of public spending. Whether this additional demand of public spending can easily be accommodated by additional taxes is however controversial, as national governments in integrated economies experience various constraints on the tax side

\footnotetext{
${ }^{4}$ See the review by [2] and, more recently, [8].

${ }^{5}$ For example, [9] show that if capital cannot be taxed with the residence principle (that would guarantee capital export neutrality), it is optimal for a small economy to tax labour only.

${ }^{6}$ This is the "fiscal termites" argument by [10] and [11]. See also [12], [13] and [14].

${ }^{7}$ See [17] and [18].

${ }^{8}$ See $[19]$.
}

of the public budget, not least because markets complain about a growth of taxes to finance what they consider unproductive public spending. ${ }^{9}$

This variety of theoretical positions hardly finds a synthesis on the empirical side, not least because of a tiny empirical evidence investigating the relationship between economic integration and tax levels. Some empirical studies give indirect support to the compensation hypothesis; ${ }^{10}$ others reinforce the intuition that economic integration is a stressing factor for public finances. ${ }^{11}$

These studies are however hardly comparable. Firstly, the existing literature does not agree on a common indicator of the tax burden, swinging from statutory tax rates to forward-looking or backward-looking effective tax rates (with various possibilities of normalisation), or to measures of tax burden based on tax ratios. ${ }^{12}$ Results may therefore be different as the indicators measure different things. Secondly, existing studies usually do not distinguish between capital taxes on mobile and immobile tax bases, which are instead crucial to capture the influence of capital mobility. Thirdly, economic integration is more often modelled as trade integration, disregarding outward and inward flows of foreign direct investments. ${ }^{13}$ As a matter of further complication, countries included often differ in number and, more importantly, by geographical areas. Some analyses are confined to OECD countries, others extend over this subset, including transitional and less developed countries. Finally, the period covered only rarely is updated to very recent times also for recent studies, with the consequence that results might be severely biased by not considering those years where economic integration has actually developed most. ${ }^{14}$

\subsection{Economic Integration and Decentralisation}

The relationship between economic integration and decentralisation is even less generously investigated; the existing studies only allow some speculations. First, the extension of the compensation hypothesis to local governments provides a straightforward link between the two

\footnotetext{
${ }^{9}$ As a result of economic integration, some authors argue that public spending would be more oriented towards privately productive public goods (e.g. infrastructures, training programmes, human capital) and less towards transfers and social welfare expenditures. See [20] and [21].

${ }^{10}$ See, for example, [16,22-27].

${ }^{11}$ See [28-34].

${ }^{12}$ For a detailed treatment of this issue, see [7].

${ }^{13}$ While this might have been an innocuous assumption in the past, the liberalization of capital markets in many advanced countries-especially in Europe in the Nineties - does not legitimate to disregard capital integration (CI) anymore. As suggested by [2] (p. 314), even though there are reasons to believe that countries with higher trade shares tend to be countries with greater capital mobility, trade openness and capital mobility are two distinctively different concepts.

${ }^{14}$ In particular, a large part of the empirical evidence stops around the first half of the Nineties, a period in which capital liberalisation is not likely to have explained all its effects, as many countries (especially in Europe) have abolished capital controls in that period.
} 
variables. Since the shield provided by social spending against additional risk is thought to be best served by centralised fiscal arrangements (e.g. [35]), the consequential outcome is that economic integration should increase the size of central governments and reduce the size of local governments, especially if regions are specialised in production. ${ }^{15}$

Second, since economic integration may reduce the cost of secession by part of small regions (e.g. [37] and [38]), exit threats may become more credible (and cheaper) in an integrated world. In turn, this may lead to an increase of the number of states, or to a larger decentralisation of existing countries in the case where requests for more autonomy are met by national governments. In the same vein, if fiscal decentralisation is interpreted as a backstop to avoid the inefficiency costs associated to secession, as in [39], more economic integration should lead to more decentralised countries. ${ }^{16}$ As before, in this case central governments would be willing to pay local governments more to avoid secession, for example, by increasing unconditional grants or by devolving more powers to sub-central units.

A third explanation tends to highlight the role of economic integration as a fiscal discipline device. In this case, economic integration would impose harder budget constraints on local governments (see [41]), reduce the "deficit bias" empirically observed in more decentralised countries - originated by either implicit or explicit bailout guarantees from the central governments ${ }^{17}$-and favour the implementation of a market-preserving federalism (e.g. [43] and [44]). ${ }^{18}$

A fourth explanation is based on the existence of opportunistic behaviour by part of either government level involved in the process. In particular, the existing literature has focused on the case where central governments may offload public expenditures to local governments. Economic integration, for example, command fiscal balance $^{19}$, may increase the domestic cost for central governments of pursuing redistributive aims ${ }^{20}$, favour more

\footnotetext{
${ }^{15}$ See also [36].

${ }^{16}$ Nonetheless, as [36] pointed out, central governments may try to "buy" the loyalty of voters by direct spending, admitting the possibility that economic integration would increase (more) the size of central governments. However, local voters might be more effectively "bought" by increasing either the size of - possibly unconditional-grants or the amount of taxes devolved to local territories. Reference [40] also provides a framework of horizontal competition among local governments in which taxpayers have wide information and comparison opportunities of local public policies.

${ }^{17}$ See, for example, [42].

${ }^{18}$ However, hard budget constraints for sub-national governments may not be socially optimal, as under some circumstances socially efficient projects may not be undertaken (see, [45]).

${ }^{19}$ This hypothesis is known as the domestic balance hypothesis. See [16].

${ }^{20}$ To some extent, the reason is the same as that predicted by [46] when perfect mobility is assumed. In this latter case, redistribution is a hardly tenable function for local governments and unstable equilibria may originate. See also [47].
}

decentralisation on a political ground, and shift responsibilities to lower government levels. ${ }^{21}$

If one assumes that the most powerful pressure to maintain fiscal balance comes from capital markets, the argument that the central governments may have incentives to offload tax powers and public spending to local governments ends up to be the argument advanced in this paper that more economic integration may lead to change the vertical structure of the public sector. It is to the empirical test of this argument that the next section is devoted.

\section{Empirical Strategy and Data}

In order to analyse the relationship between economic integration, tax erosion and decentralisation, we follow a two-stage empirical strategy based on two hypotheses:

Hypothesis 1

Economic integration would erode the tax revenues raised by central governments on mobile capital (more generally on mobile tax bases).

Hypothesis 2

Tax erosion experienced by central governments leads to an increase of public sector decentralisation.

A theoretical intuition of the implications of these two hypotheses can be gained by making recourse to the concept of the Marginal Efficiency Cost of Funds (MECF) developed by [50]. As argued above, the central government may try to shift tax responsibilities to other government levels whenever it faces higher marginal efficiency costs in raising its own additional tax revenues. To this purpose, suppose that a central government collects tax revenue $R_{C}$ according to the following scheme:

$$
R_{C}=t_{r} \Upsilon_{r}\left(t_{r}\right)+t_{n r} \Upsilon_{n r}\left(t_{n r}\right)
$$

where $t_{r}$ is the tax rate applied on the "resident" tax base $r_{r}$ and $t_{n r}$ is the tax rate on the "non-resident" tax base $\gamma_{n r}$, where "resident" and "non resident" can be here interpreted as relatively immobile and mobile tax bases, respectively. Now, the efficiency cost of collecting funds either from resident or non-resident tax bases depends on the level of additional tax revenue that can be obtained by increasing the corresponding tax rate. To this purpose, define:

$$
\begin{gathered}
M R_{r} \equiv \frac{\mathrm{d} R}{\mathrm{~d} t_{r}}=\Upsilon_{r}\left(t_{r}\right)+t_{r} Y_{r}^{\prime}\left(t_{r}\right) \\
M R_{n r} \equiv \frac{\mathrm{d} R}{\mathrm{~d} t_{n r}}=\Upsilon_{n r}\left(t_{n r}\right)+t_{n r} Y_{n r}^{\prime}\left(t_{n r}\right)
\end{gathered}
$$

\footnotetext{
${ }^{21}$ The origin of the shifting hypothesis can be traced back to the literature on regulation authorities. See, for example, [48]. Reference [49], for example, argue that strategic behavior may be followed by central governments when facing increasing pressures to maintain fiscal balance, in particular by offloading expenditures and deficits to local governments.
} 
as the marginal revenue that can be obtained by moving either $t_{r}$ or $t_{n r}$, with

$$
Y_{r}^{\prime}\left(t_{r}\right)=\frac{\mathrm{d} Y_{r}}{\mathrm{~d} t_{r}} .
$$

Equations (2) and (3) can be interpreted as the sum of the "tax rate effect" $\left(Y_{r}\left(t_{r}\right)\right)$ and of the "tax base effect" $\left(t_{r} Y_{r}^{\prime}\left(t_{r}\right)\right)$. In particular, one could also rewrite

$$
M R_{j}=r_{j}-\left(r_{j}-M R_{j}\right),
$$

$j=r, n r$, by which the marginal revenue is defined by the "potential tax base" $\left(r_{j}\right)$ minus the "leak" represented by $\left(r_{j}-M R_{j}\right)$.

Now, by normalising both (2) and (3) by the potential tax base $r_{r}$ and $r_{n r}$, respectively, one can get the marginal revenue per unit of tax base:

$$
\frac{M R_{j}}{r_{j}}=1+\varepsilon_{r_{j}, t_{j}}
$$

where $j=r, n r$ and

$$
\varepsilon_{r_{j}, t_{j}}=\frac{t_{j} Y_{r}^{\prime}}{r_{j}}
$$

It is clear that when $\varepsilon_{r_{j}, t_{j}}=0$, one unit of tax base gives $d t_{j}$ units of additional tax revenues. By (4), the definition of the marginal efficiency cost of fund arises by taking its inverse:

$$
M E C F_{j}=\frac{r_{j}}{M R_{j}}=\frac{1}{1+\varepsilon_{r_{j}, t_{j}}}
$$

The general principle follows from (5) that the MECF will be greater for more elastic tax bases, while it will be smaller in the case of less elastic tax bases. Since it can be assumed that tax bases that may migrate are more elastic to tax rates, it will be that $\left|\varepsilon_{r_{n r}, t_{n r}}\right|>\left|\varepsilon_{r_{r}, t_{r}}\right|$ and $M R_{n r}<M R_{r}$ (i.e. the marginal revenue that can be obtained by taxing non-residents is lower as part of the tax base would disappear). This latter condition implies $M E C F_{n r}>M E C F_{r}$, i.e., a higher MECF on more mobile tax bases, signalling growing difficulties in using those tax bases (Stiglitz, 2003).

Thus, if the central government has a target level of tax revenue, it has some convenience to shift taxation from mobile to immobile tax bases, as this minimises the "leak" of tax revenues. Thus, growing economic integration may encourage, on an efficiency ground, a shift of taxation on less mobile ("resident") tax bases (e.g., labour or immovable properties). Now, since the most mobile tax bases are usually assigned to central governments and immobile tax bases are instead widely used by local governments, growing economic openness may entail a change in the vertical structure of taxation among government levels.
Of course, this may occur at different speeds in various countries, but there is some consensus that economic integration, in recent years, may have accelerated a shift of power away from politics and towards economics. As recently observed ([51], p. 13), the power of politics (to be extended to the power of taxation) has weakened because of several interrelated reasons. First, economic integration has enhanced the number of tradable goods and services in the financial sector (i.e., the most mobile production factor). Second, to the extent that multinational corporations are the primary owners of mobile production factors, they enjoy a strengthened leverage with respect to territorial actors (i.e. those owning relatively immobile production factors like land and labour). Third, markets have outgrown states in size, which implies that states have growing difficulties to regulate and tax markets unless political institutions are adjusted accordingly.

These external pressures would therefore beg the question of whether one can expect a reallocation of public goods provision among government levels. Presumably, global economic pressures have increased the necessity to shift resource allocation beyond national frontiers ([51], p. 26) and reinforced the case to devolve both stabilization and redistributive functions to supranational governments. $^{22}$ At the same time, they might have forced states to devolve to sub-national governments all matters that they can efficiently deal with, especially with regard to the allocation function.

In this latter case, decentralisation of taxation and spending powers may provide a mixed outcome. On the one hand, it may favour a better correspondence between spending and taxes at local level (the benefit principle of taxation); it may reduce the domestic costs of redistribution by insulating redistributive local spending and taxation from global pressures; and efficiency may improve because of incentives for local governments to behave more competitively. ${ }^{23}$ On the other hand, decentralisation may be opportunistically used to distribute the tax collecting points on a territorial basis, by this way promoting tax illusion, and to strategically shift external constraints to local governments in various institutional forms (e.g., Internal Stability Pacts in the European countries). Thus, whether decentralisation is actually pursued in the presence of growing economic integration, depends on the balance between political advantages and disadvantages. As such, it is a matter of empirical evidence, which is embodied in our hypothesis 2 .

For an empirical assessment of the two hypotheses, we

\footnotetext{
${ }^{22}$ One exploited argument to limit national redistributive policies is that they are perceived as being responsible for reducing incentives to work and to invest (e.g., [52]).

${ }^{23}$ The absence of competition among governmental units, for example, was at the base of the pioneering contribution by [53] on the European integration.
} 
have built an unbalanced panel of 16 OECD countries for a total of 469 observations (see Table A.1 in Appendix). Data are taken by a number of sources: the main source for all tax variables is OECD, while for the degree of economic integration we have made recourse to data from the International Monetary Fund. Real income at PPP is finally taken by the Penn World Tables (see Table A.1).

Hypothesis 1 is tested in the first stage of an econometric procedure, where economic integration enters as an explanatory variable of tax levels as measured by the implicit tax rates. In particular, the first stage consists of estimating the following equation by a feasible generalised least squares (FGLS) controlling for heteroskedasticity and panel-specific first-order autocorrelation: ${ }^{24}$

$$
\begin{aligned}
\operatorname{lgs}\left(\operatorname{ITR}_{i, t}^{h}\right)= & \alpha^{h}+\beta_{1}^{h} \operatorname{lgs}\left(\text { ITR }_{i, t-1}^{h}\right)+\beta_{2}^{h} \ln \left(\text { OPEN }_{i, t}\right) \\
& +\beta_{3}^{h}\left(\ln \left(\text { OPEN }_{i, t}\right)\right)^{2}+\sum_{i=1}^{N} \theta_{i}^{h} d_{i} \ln \left(\text { OPEN }_{i, t}\right) \\
& +\sum_{p=1}^{P} \eta_{p} \ln \left(X_{i, t}^{p}\right)+e_{i, t}
\end{aligned}
$$

where $\operatorname{lgs}\left(I T R_{i, t}^{h}\right)$ is the logistic transformation of the implicit tax rate falling on the tax base $h$ in country $i$ at time $t$, where $h$ is, alternatively, labour income, consumption, immobile capital, and mobile capital. ${ }^{25}$ It is worth noting that the distinction between tax rates on immobile and mobile capital remedies the often observed practice, in empirical studies, of including taxes on corporations and on immovable properties under the same heading of "capital tax rates". Indeed, the expected reactions of these two effective tax rates to economic integration may be significantly diversified and would require to be separately measured. Even though, in principle, implicit tax rates on all taxes might decline with increasing economic openness (what we have defined as the process of tax erosion), one can expect a larger decline of implicit tax rates on the most mobile tax bases. As a consequence, when the power to tax these tax bases is concentrated in the hands of the central government, this would mainly entail an erosion of the central government tax revenues.

The other variables in Equation (6) have the following meaning. Economic openness $(\ln ($ OPEN $))$ is defined

\footnotetext{
${ }^{24}$ The null hypothesis of no panel-level heteroskedasticity is rejected. A test of first-order autocorrelation within each panel has been performed via the time-series cross-section equivalent of the standard Lagrange multiplier test. Results of the test are not reported in table.

${ }^{25}$ Full details of this procedure are given in [7] and summarised in Table A.1. For mobile capital, two different methods to calculate the appropriate tax bases have been used: a) net operating surplus of corporations computed with the OECD methodology (OM2); b) net operating surplus of corporations computed as in [6] taking into account the correction proposed by [54] (OMM2). In both cases only corporations are considered.
}

as the sum of exports, imports, and both inward and outward foreign direct investment as a share of GDP, aimed at capturing the degree of potential mobility in the most comprehensive way; ${ }^{26} d_{i} \ln \left(O P E N_{i, t}\right)$ is an interaction term between a country dummy and the variable $\ln ($ OPEN $)$, which will prove useful to calculate country-specific elasticities; $X$ is a vector of control variables including: population and per capita income in US\$, to control for demographic and wealth; general government expenditures as a percentage of GDP, to control for government size; ITR $R_{i, t}^{k}$ for $k \neq h$, to control for the existing tax structure; and a vector of year dummy variables, to control for time effects. In addition, a standard measure of the total fiscal burden has also been considered, approximated by the ratio between total tax revenues and GDP.

When Equation (6) produces statistically significant coefficients, a set of country-specific elasticities of implicit tax rates with respect to economic integration can be derived. In particular, by indicating with $k \neq h \hat{\beta}_{j}^{h}(j \in\{2,3\})$ and $\hat{\theta}_{i}^{h}(i \in\{1 \cdots N\})$ the estimated value of the parameters in (6), the elasticities $\hat{E}_{i, t}^{h}$ will be given by:

$$
\hat{E}_{i, t}^{h}=\hat{\beta}_{2}^{h}+2 \hat{\beta}_{3}^{h} \ln \left(O P E N_{i, t}\right)+\hat{\theta}_{i}^{h} d_{i}
$$

Equation (7) is particularly important for our argument. More specifically, $\hat{E}_{i, t}^{h}>0$ would imply that implicit tax rates will increase with economic integration, while $\hat{E}_{i, t}^{h}<0$ would imply the opposite. In a static perspective, tax erosion will emerge only when this latter condition is satisfied, which means that a country is at a stage where a further growth of economic integration would reduce the effective tax burden on the specific tax base $h$. However, in a dynamic perspective, tax erosion cannot be excluded by $\hat{E}_{i, t}^{h}>0$, provided that $\hat{E}_{i, t}^{h}$ follows a decreasing pattern over time. In this case, even though the tax burden on $h$ grows with economic integration, the decreasing rate of growth over time would signal a process of tax erosion. ${ }^{27}$

Equipped with the elasticities estimated in the first stage, the second stage of the econometric procedure provides a test of hypothesis 2 , in order to verify the impact of $\hat{E}_{i, t}^{h}$ on the degree of decentralisation. To this purpose, the following equation is estimated:

$$
\begin{aligned}
& \Delta_{t} \ln \left(D_{i}\right)=\gamma^{h}+\delta_{1}^{h} \Delta_{t-1} \ln \left(D_{i}\right)+\delta_{2}^{h} \Delta_{t-2} \ln \left(D_{i}\right) \\
& +\varphi^{h} \Delta_{t} \hat{E}_{i}^{h}+\sum_{q=1}^{Q} \psi_{q}^{h} \Delta_{t} \ln \left(Z_{i}^{q}\right)+u_{i, t}
\end{aligned}
$$

\footnotetext{
${ }^{26}$ See [55] for an application of these measures. This comprehensive measure aims at giving a synthetic indication of the total international exposure of a country. For this reason, OPEN takes into account both trade and investment indicators and, indirectly, their different growth rates over the last decades.

${ }^{27}$ Reference [56], for example, have argued that if capital owners shift capital out of high-tax jurisdictions, governments may be forced to increase the effective tax burden on capital in order to maintain the same revenue from an eroding tax base.
} 
where, for a generic variable $x, \Delta_{t} x=x_{t}-x_{t-1} ; D$ is the degree of decentralisation as measured by the ratio between local and total public spending; $Z$ is a vector of control variables that are a subset of the control variables included in the first stage regression and $\hat{E}_{i, t}^{h}$ is the previously estimated elasticity. ${ }^{28}$ Note that in this second stage regression, system-GMM estimators are used, to take into account dynamics and possible endogeneity issues. A negative sign of $\varphi^{h}$ is what we are looking for to support hypothesis 2 for each tax base $h$.

\section{Results}

\subsection{The First Stage Relationship between Economic Integration and Implicit Tax Rates}

Table 1 reports a set of five regressions (with a Feasible Generalised Least Squares method), experimenting Equation (6) first on a global measure of tax burden (total taxes over GDP, in column A) and then on specific measures of implicit tax rates. In particular, the same model has been estimated considering ITR on mobile capital (tKS_OMM2 in column B), on labour income (tL_O in column $\mathrm{C}$ ), on consumption ( $\mathrm{tC}$ _ $\mathrm{E}$ in column $\mathrm{D})$ and on immobile capital (tKK_OM2 in column E). In all cases, the list of regressors includes the one-period lagged dependent variable, to take into account the persistency of tax variables. The other explanatory variables are the same across regressions, including a vector of interaction terms between economic integration and country dummy variables and a vector of year dummy variables (whose coefficients are not reported in table). As noted above, the set of control variables includes $I T R_{i, t}^{k}$ for $k \neq h$.

To our aims, the key finding involves the sign of the coefficients of economic integration (OPEN), with a negative sign supporting a process of tax erosion (hypothesis 1). Our results show that this process has statistical significance only for taxes on mobile capital (column B). The coefficients of OPEN and OPEN2 are both negative, signalling that growing economic integration may not only generate a downward pressure on implicit tax rates on mobile capital, but also that this pressure may grow at increasing rates. The coefficients of $I T R_{i, t}^{k}$ also show that the implicit tax rate on mobile capital is inversely related to the implicit tax rate on labour. This suggests that when economic integration leads to a reduction of the tax burden on mobile tax bases, part of the compensating effect is likely to fall on labour, rather than on other tax bases. This conclusion is reinforced by the results in columns $\mathrm{B}$ and $\mathrm{C}$, where implicit tax rates on

\footnotetext{
${ }^{28}$ Following [57] the latter requirement generates consistent standard errors from the estimation of Equation (8), which includes the "generated" regressor $\hat{E}_{i, t}^{h}$. See, in particular, the theorems 3.iii, 4 and 5.
}

labour and mobile capital have an opposite path in both cases.

The outcomes reported in columns $\mathrm{C}$ to $\mathrm{E}$, instead, suggest that the other implicit tax rates (on labour, consumption and immobile capital) are not directly affected by economic integration. It means, as expected, that the main impact of economic integration falls on taxes on mobile capital; and that the other tax bases are natural candidates to backstop the tax erosion induced by economic integration. Unlike other studies on the same topic, it is particularly important that these results are captured after separating ITRs on mobile and immobile capital. The result that only specific tax bases react to economic integration could also partially explain why the coefficients of OPEN are not statistically significant when the regression is run using total tax revenues over GDP as a dependent variable (column A). Indeed, these comprehensive measures of tax burden may conceal opposite patterns of tax revenues collected on different tax bases, giving the wrong impression that nothing is happening.

As tax erosion cannot be supported for other tax bases, the only meaningful set of elasticities of ITRs with respect to economic integration can be estimated for mobile capital $\left(\hat{E}_{i, t}^{K S}\right)$. This is done in Table 2, where country-average elasticities are calculated. Elasticities are either positive or negative and, with the exception of Austria, all of them are statistically significant at 1 per cent level. As discussed above, from a static perspective, a negative elasticity is a sufficient condition to state that a process of tax erosion has already taken place, the meaning being that the implicit tax rate would fall when economic integration grows. A positive sign, instead, would signal that growing levels of openness may be consistent with a growth of implicit tax rates.

A negative sign (calculated at the average level of openness) appears only in three countries (Germany, Italy and the Netherlands) and may be partially justified by the fact that, for most countries, our dataset extend from 1973 to 2005, with only the last decade particularly buoyant in terms of flows of trade and foreign direct investments. In other terms, a process of erosion may be in place that is only observed since few years or will be more likely observed in the next years. To capture the possible presence of this trend in the period observed, one can consider a dynamic perspective, where what actually matters is not the point estimate of the elasticities, but their change over the time span.

To this purpose, the last column of Table 2 reports the difference between the elasticity measured in the first and in the last year in which each country is observed in the dataset. The overwhelming prevalence of negative signs (with the exception of Canada) indicates that, even when positive, elasticities decrease over time, i.e., ITRs on mobile capital grow slowly when economic integra- 
Table 1. Economic integration and implicit tax rates: A panel analysis.

\begin{tabular}{|c|c|c|c|c|c|c|c|c|c|c|}
\hline Method & \multicolumn{2}{|c|}{ FGLS } & \multicolumn{2}{|c|}{ FGLS } & \multicolumn{2}{|c|}{ FGLS } & \multicolumn{2}{|c|}{ FGLS } & \multicolumn{2}{|c|}{ FGLS } \\
\hline Dependent Variable & \multicolumn{2}{|c|}{ tax_GDP } & \multicolumn{2}{|c|}{ tKS_OMM2 } & \multicolumn{2}{|c|}{$t L \_O$} & \multicolumn{2}{|c|}{$t C \_E$} & \multicolumn{2}{|c|}{ tKK_OM2 } \\
\hline & \multicolumn{2}{|l|}{ A } & \multicolumn{2}{|l|}{$\mathbf{B}$} & \multicolumn{2}{|l|}{ C } & \multicolumn{2}{|c|}{$\mathbf{D}$} & \multicolumn{2}{|l|}{$\mathbf{E}$} \\
\hline Regressors & Coefficients & Sig. level & Coefficients & Sig. level & Coefficients & Sig. level & Coefficients & Sig. level & Coefficients & Sig. level \\
\hline$t a x \_G D P_{(t-1)}$ & 0.886 & $* * *$ & & & & & & & & \\
\hline$t K S \_O M M 2_{(t-1)}$ & & & 0.707 & $* * *$ & & & & & & \\
\hline$t L O_{(t-1)}$ & & & & & 0.896 & $* * *$ & & & & \\
\hline$t C \_E_{(t-1)}$ & & & & & & & 0.878 & $* * *$ & & \\
\hline$t K K \_O M 2_{(t-1)}$ & & & & & & & & & 0.840 & $* * *$ \\
\hline OPEN & -0.060 & & -0.5438 & $* * *$ & -0.073 & & 0.036 & & 0.178 & \\
\hline$O P E N^{2}$ & -0.032 & $*$ & -0.2420 & $* * *$ & -0.034 & & 0.007 & & 0.084 & \\
\hline lggov & -0.003 & & -0.0110 & & -0.004 & & -0.003 & & 0.014 & \\
\hline Ipopulation & -0.030 & $* * *$ & -0.1242 & $* *$ & -0.031 & $* *$ & -0.042 & $* * *$ & 0.154 & $* * *$ \\
\hline linc_us2 & 0.073 & $* *$ & 0.1870 & & 0.045 & & 0.019 & & -0.092 & \\
\hline tKS_OMM2 & & & & & -0.039 & $* * *$ & 0.025 & $* * *$ & 0.121 & $* * *$ \\
\hline$t L \_O$ & & & -0.2521 & $* * *$ & & & 0.022 & $*$ & 0.109 & $* *$ \\
\hline$t C \_E$ & & & 0.1781 & $* * *$ & 0.032 & & & & 0.105 & $*$ \\
\hline$t K K \_O M 2$ & & & 0.0955 & $* * *$ & 0.026 & $* * *$ & 0.002 & & & \\
\hline dOPEN_AU & 0.044 & & 0.2692 & $*$ & 0.009 & & 0.042 & & -0.099 & \\
\hline dOPEN_DEN & 0.007 & & 0.9264 & $* * *$ & 0.094 & & -0.060 & & -0.566 & $* * *$ \\
\hline dOPEN_FIN & 0.031 & & 0.5314 & $* * *$ & 0.007 & & -0.009 & & -0.160 & \\
\hline dOPEN_FR & -0.046 & $* *$ & 0.1497 & $* *$ & -0.028 & & -0.061 & $* *$ & -0.008 & \\
\hline dOPEN_GE & -0.015 & & 0.0223 & & -0.051 & & -0.053 & $*$ & 0.240 & $* * *$ \\
\hline dOPEN_GR & 0.018 & & 0.4065 & $* * *$ & -0.002 & & -0.025 & & -0.047 & \\
\hline dOPEN_IT & -0.031 & & 0.1213 & & -0.096 & $* * *$ & -0.050 & $* *$ & 0.159 & $* *$ \\
\hline dOPEN_NL & -0.044 & & 0.3999 & * & -0.134 & & 0.055 & & -0.043 & \\
\hline dOPEN_PO & 0.044 & & 0.4509 & $*$ & 0.077 & & -0.022 & & -0.240 & \\
\hline dOPEN_SW & -0.010 & & 0.5230 & $* * *$ & -0.024 & & 0.000 & & -0.177 & \\
\hline dOPEN_UK & -0.015 & & 0.3616 & $* * *$ & 0.077 & $* *$ & -0.073 & $* * *$ & -0.249 & $* * *$ \\
\hline dOPEN_AUS & 0.049 & $* *$ & 0.3312 & $* * *$ & 0.067 & $* *$ & 0.014 & & -0.251 & $* * *$ \\
\hline dOPEN_CAN & 0.027 & & 0.5197 & $* * *$ & 0.072 & $*$ & -0.002 & & -0.399 & $* * *$ \\
\hline dOPEN_NOR & 0.087 & $*$ & 0.8026 & $* * *$ & 0.117 & $*$ & -0.030 & & -0.329 & $*$ \\
\hline dOPEN_SP & -0.005 & & 0.3150 & $* * *$ & 0.001 & & -0.033 & & -0.119 & \\
\hline Constant & -0.679 & $*$ & -1.489 & & -0.332 & & -0.153 & & 0.410 & \\
\hline Year dummy variables & Yes & & Yes & & Yes & & Yes & & Yes & \\
\hline Number of observations & 452 & & 452 & & 452 & & 452 & & 452 & \\
\hline Number of countries & 16 & & 16 & & 16 & & 16 & & 16 & \\
\hline Wald chi ${ }^{2}$ & (53) 31474 & $.94 * * *$ & (56) 5735 . & $36 * * *$ & (56) 28640 . & $.89 * * *$ & (56) 7121 & $4.84 * * *$ & (56) 16914 & $24 * * *$ \\
\hline \multirow{2}{*}{ Panels } & \multicolumn{2}{|c|}{ Heteroskedastic } & \multicolumn{2}{|c|}{ Heteroskedastic } & \multicolumn{2}{|c|}{ Heteroskedastic } & \multicolumn{2}{|c|}{ Heteroskedastic } & \multicolumn{2}{|c|}{ Heteroskedastic } \\
\hline & Panel-speci & fic $A R(1)$ & Panel-speci| & fic $A R(1)$ & Panel-specif & fic $A R(1)$ & Panel-speci & fic $A R(1)$ & Panel-specif & $c A R(1)$ \\
\hline
\end{tabular}

Note: *** $1 \%$ significance level; ** 5\% significance level; * 10\% significance level; ggov, population, inc_us 2 are introduced in logarithms. tax_GDP, $t K S \_O M M 2, t K K \_O M 2, t C \_E, t L \_O$ are logistic transformations of the original variables. Source: authors' elaborations. 
Table 2. The elasticity of implicit tax rates.

\begin{tabular}{ccccccc}
\hline Country & $\begin{array}{c}\text { Mean } \\
\text { elasticity }\end{array}$ & S.E. & $\begin{array}{c}\text { Sig. } \\
\text { level }\end{array}$ & $\begin{array}{c}\text { First year } \\
\text { observed }\end{array}$ & $\begin{array}{c}\text { Last year } \\
\text { observed }\end{array}$ & Difference \\
\hline Australia & 0.435 & 0.014 & $* * *$ & 0.559 & 0.323 & -0.236 \\
Austria & 0.016 & 0.016 & & 0.124 & -0.205 & -0.329 \\
Canada & 0.256 & 0.022 & $* * *$ & 0.303 & 0.368 & 0.065 \\
Denmark & 0.657 & 0.015 & $* * *$ & 0.730 & 0.537 & -0.192 \\
Finland & 0.298 & 0.018 & $* * *$ & 0.377 & 0.184 & -0.193 \\
France & 0.067 & 0.016 & $* * *$ & 0.207 & -0.073 & -0.280 \\
Germany & -0.153 & 0.016 & $* * *$ & 0.022 & -0.357 & -0.379 \\
Greece & 0.482 & 0.025 & $* * *$ & 0.569 & 0.454 & -0.115 \\
Italy & -0.061 & 0.012 & $* * *$ & 0.044 & -0.161 & -0.204 \\
Netherlands & -0.095 & 0.014 & $* * *$ & 0.021 & -0.266 & -0.286 \\
Norway & 0.548 & 0.006 & $* * *$ & 0.549 & 0.492 & -0.058 \\
Portugal & 0.185 & 0.012 & $* * *$ & 0.307 & 0.217 & -0.091 \\
Spain & 0.304 & 0.027 & $* * *$ & 0.517 & 0.138 & -0.378 \\
Sweden & 0.254 & 0.018 & $* * *$ & 0.440 & 0.108 & -0.332 \\
United & 0.184 & 0.009 & $* * *$ & 0.261 & 0.149 & -0.113 \\
Kingdom & & & & & & \\
United & 0.316 & 0.019 & $* * *$ & 0.606 & 0.162 & -0.444 \\
States & & & & & & \\
Total & 0.153 & 0.015 & $* * *$ & & & \\
\hline
\end{tabular}

Note: $* * * \quad 1 \%$ significance level; $* * \quad 5 \%$ significance level; * $10 \%$ significance level. Source: authors' elaborations.

tion grows. For five countries (Austria, France, Germany, Italy, and the Netherlands), elasticities start on the positive and end up on the negative side, signalling that an erosion process has developed. In all other cases, the smaller positive values indicate that growing economic integration has entailed a progressively lower additional tax burden. In other words, a decreasing trend of positive elasticities is a signal that the ability to extract tax revenues from mobile capital is declining over time and eventually evolve towards erosion. Thus, our estimates (and our measure of economic openness) seem to correctly pick some important characteristics of the process of economic integration and this is actually what is perceived in Figure 1. Here, both the estimated values of the elasticities and a polynomial trend of order two are included in each graph. With very few exceptions, it is clear that, in the period observed, the trend of $\hat{E}_{i, t}^{K S}$ is declining in most countries.

\subsection{The Second Stage Relationship between Elasticities and Decentralisation}

The estimation of $\hat{E}_{i, t}^{K S}$ allows us to move towards the second stage of the analysis, whose aim is to investigate whether the process of tax erosion at the central level may cause second-round effects on the vertical structure of the public sector. As discussed in Section 3, our maintained hypothesis is that, following growing constraints on the action of the central government, the process of tax erosion would stimulate fiscal decentralisation. At this stage, our method of estimation shifts towards a GMM technique, where changes of the relevant variables are considered. This method would more properly take into account that the dependent variable is persistent over time, that some regressors may be endogenous, and that time-invariant country characteristics may be correlated with the explanatory variables. All these issues may be addressed by moving either to a difference-GMM ([58]) or to a system-GMM ([59] and [60]).

Results are reported in Table 3. Column A gives the outcome of the difference-GMM by [58]. The sign of $\varphi^{K S}$ is negative as expected. Thus, lower values of the elasticities (i.e., a more intense tax erosion) are associated to greater decentralization levels. This implies that, regardless of its initial sign, the change of the elasticity would foster a process of decentralisation, where taxes on less mobile tax bases are possibly applied to compensate the lower tax revenues raised on mobile tax bases. This may also explain why economic integration does not affect taxes on immobile capital, as a large share of these taxes are already used by local governments to secure tax revenues from competitive pressures and to backstop the tax erosion affecting mobile tax bases used by central governments.

Our preferred explanation is that when central governments find mounting difficulties in managing tax bases, they are more incline to decentralise all competencies local governments can efficiently deal with in agreement with the subsidiarity principle. This allows central governments to reduce the size of public spending, by contemporaneously shifting external constraints to local governments in various institutional forms, of which, for example, Internal Stability Pacts introduced in many European countries may be the most visible form. Following this line of reasoning, the degree of decentralisation would increase when economic integration grows, as a result of a deliberate choice of the central government to share tax and spending constraints with other government levels and therefore with other political constituencies.

Column B replicates the difference-GMM by taking into account that our panel is unbalanced and that the first-differencing transformation may magnify gaps. Following [58], we re-estimate the difference-GMM using an orthogonal transformation ([61]), by which the average of all future available observations is subtracted to the current observation. Again, the coefficient of the elasticity is negative and statistically significant.

Since in both cases of difference-GMM, the validity of instruments is supported by AR and Sargan tests, it would not be required to improve the estimation by performing a system-GMM. However, as a further robustness check, column $\mathrm{C}$ shows the corresponding outcome. System-GMM uses the equation in levels and the equa- 


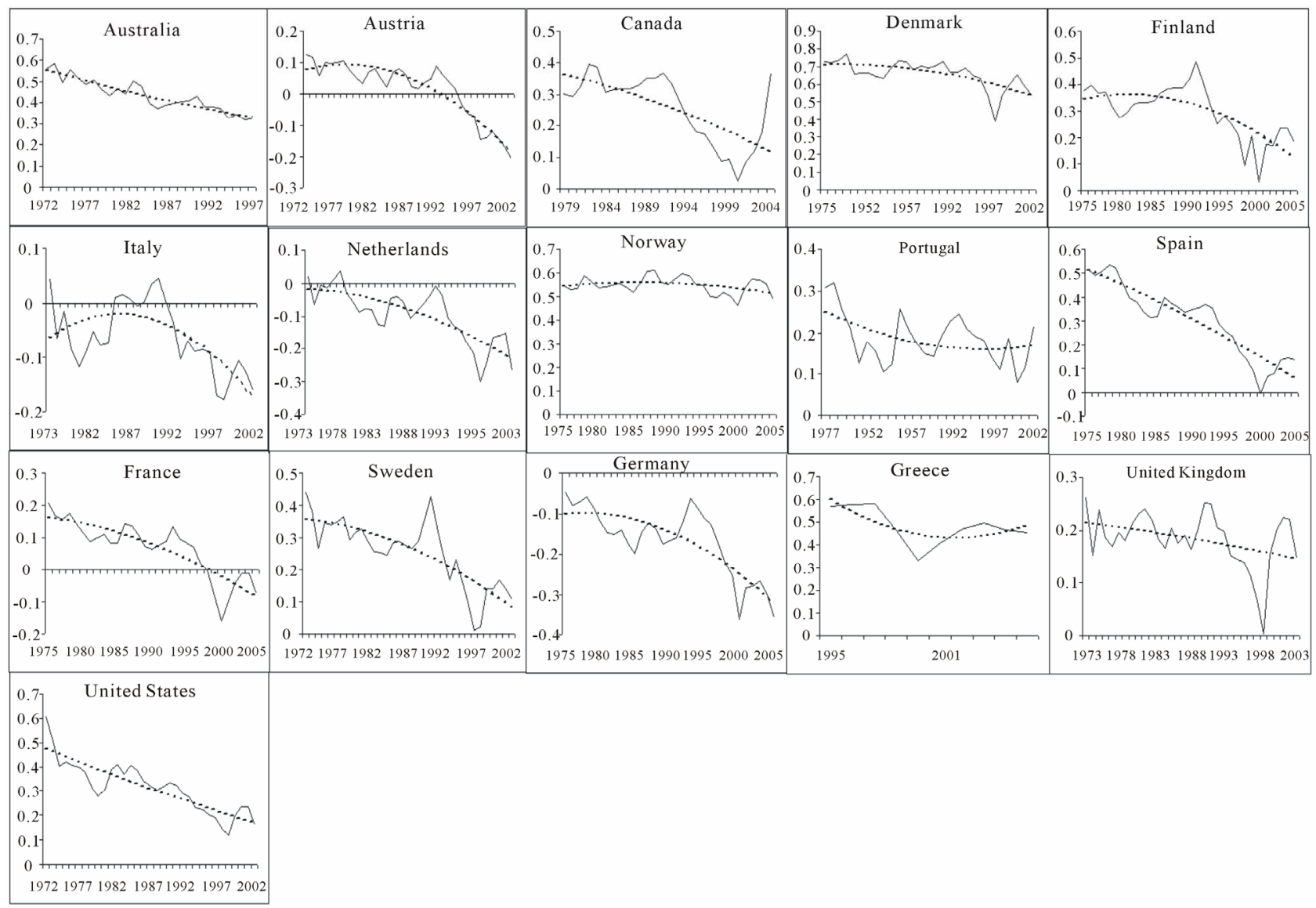

Figure 1. Elasticities of the ITR on mobile capital with respect to economic integration (source: authors' elaborations).

Table 3. Tax erosion and decentralisation.

\begin{tabular}{|c|c|c|c|c|c|c|}
\hline Method & \multicolumn{2}{|c|}{ A) Difference-GMM } & \multicolumn{2}{|c|}{ B) Difference-GMM } & \multicolumn{2}{|c|}{ C) System-GMM } \\
\hline Dependent Variable & \multicolumn{2}{|c|}{ lloc } & \multicolumn{2}{|c|}{ lloc } & \multicolumn{2}{|c|}{ lloc } \\
\hline Regressors & Coefficients & Sig. level & Coefficients & Sig. level & Coefficients & Sig. level \\
\hline $\operatorname{lloc}_{(t-1)}$ & 0.9411 & $* * *$ & 0.9550 & $* * *$ & 0.5905 & $* * *$ \\
\hline $1 l o c_{(t-2)}$ & -0.0324 & & -0.0426 & & -0.1891 & \\
\hline lggov & 0.0015 & & 0.0011 & & 0.0004 & \\
\hline lpopulation & -0.0590 & & -0.0564 & & 0.4048 & \\
\hline linc_us2 & 0.0381 & $*$ & 0.0248 & & 0.1270 & \\
\hline$E$ & -0.1029 & $* * *$ & -0.1060 & $* * *$ & -0.1521 & $* * *$ \\
\hline Constant & -0.2837 & & -0.1548 & & -3.1944 & $* *$ \\
\hline Number of observations & 415 & & 434 & & 434 & \\
\hline Number of countries & 16 & & 16 & & 16 & \\
\hline Wald chi ${ }^{2}$ & (6) 3373.1 & $* * *$ & (6) 4227.7 & $* * *$ & (6) 383.4 & $* * *$ \\
\hline Sargan test $\left(c h i^{2}\right)$ & 424,9 & & 423,2 & & 2,8 & \\
\hline Number of instruments & 409 & & 411 & & 569 & \\
\hline No first order autocorrelation & -2.3 & $* *$ & -10.9 & $* *$ & $-1,8$ & $*$ \\
\hline No second order autocorrelation & -0.4 & & -0.2 & & 0.7 & \\
\hline Transformation & First Difference & & Orthogonal & & & \\
\hline
\end{tabular}

Note: *** $1 \%$ significance level; ** 5\% significance level; * 10\% significance level; loc, ggov, population, inc_us 2 are introduced in logarithms. Source: authors' elaborations. 
tion in difference to obtain a system of two equations and to get additional instruments, with the requirement that the first difference of the instruments used in the level equation should not be correlated with unobserved country specific effects. Since taxes may possibly be correlated with some unobserved effects, we choose to instrument only the difference equation. Column $\mathrm{C}$ shows, once again, that the coefficient of the elasticity supports the idea that the degree of decentralisation may increase with economic integration.

\section{Concluding Remarks}

This paper has empirically investigated two related issues for a sample of OECD countries. First, whether and how the degree of economic openness may affect central government tax revenues. Second, whether and how the process of tax erosion at central level may cause secondround effects on the vertical structure of the public sector.

To address the first issue we have estimated an equation where economic integration enters as an explanatory variable of implicit tax rates (ITRs) of four tax bases (labour, mobile capital, immobile capital and consumption) as well as of a global measure of the tax burden. The results show that the process of tax erosion induced by economic integration has statistical significance only for taxes on mobile capital, and that part of the compensating effect is likely to fall on labour, rather than on other tax bases.

With regard to the second issue investigated in this paper, our results suggest that the increasing difficulties faced by central governments in collecting additional tax revenues from mobile capital would be associated to an increase of the size of sub-central units. Our explanation is that when central governments find mounting difficulties in managing tax bases, they are more inclined to decentralise competencies to local governments and to boost the decentralization process. This would allow them to reduce the size of the central public spending, by strategically shifting external constraints to local governments in various institutional forms.

\section{REFERENCES}

[1] I. Grunberg, "Double Jeopardy: Globalization, Liberalization and the Fiscal Squeeze," World Development, Vol. 26, No. 4, 1998, pp. 591-605. http://dx.doi.org/10.1016/S0305-750X(97)10068-7

[2] G. Schulze and H. W. Ursprung, "Globalization of the Economy and the Nation State," The World Economy, Vol. 22, No. 3, 1999, pp. 295-352. http://dx.doi.org/10.1111/1467-9701.00205

[3] J. Stiglitz, "Globalization and the Economic Role of the State in the New Millennium," Industrial and Corporate Change, Vol. 12, No. 1, 2003, pp. 3-26. http://dx.doi.org/10.1093/icc/12.1.3

[4] D. Stegarescu, "The Effects of Economic and Political Integration on Fiscal Decentralization: Evidence from OECD countries," Canadian Journal of Economics, Vol. 42, No. 2, 2009, pp. 694-718. http://dx.doi.org/10.1111/j.1540-5982.2009.01524.x

[5] P. Liberati and A. Scialà, "How Economic Integration Affects the Vertical Structure of Public Sector," Economics of Governance, Vol. 12, No. 4, 2011, pp. 385-402. http://dx.doi.org/10.1007/s10101-011-0097-Z

[6] E. G. Mendoza, A. Razin and L. L. Tesar, "Effective Tax Rates in Macroeconomics: Cross-Country Estimates of Tax Rates on Factor Incomes and Consumption," NBER Working Paper 4864, 1994.

[7] F. Gastaldi, "Globalisation, Capital Mobility and Convergence of Effective Tax Rates," CRISS Working Paper, No. 32, 2008.

[8] F. Gastaldi and P. Liberati, "Economic Integration and Government Size: a Review of the Empirical Literature," Financial Theory and Practice, Vol. 35, No. 3, 2011, pp. 327-384.

[9] S. Bucovetsky and J. Wilson, "Tax Competition with Two Tax Instruments," Regional Science and Urban Economics, Vol. 21, No. 3, 1991, pp. 333-350. http://dx.doi.org/10.1016/0166-0462(91)90062-R

[10] V. Tanzi, "Taxation in an Integrating World," Brookings Institutions, Washington DC, 1995.

[11] V. Tanzi, "Globalization and the Future of Social Protection," Scottish Journal of Political Economy, Vol. 49, No. 1, 2002, pp. 116-127. http://dx.doi.org/10.1111/1467-9485.00224

[12] D. R. Lee and R. B. McKenzie, "The International Political Economy of Declining Tax Rates," National Tax Journal, Vol. 42, No. 1, 1989, pp. 79-83.

[13] P. Kurzer, "Business and Banking: Political Change and Economic Integration in Western Europe," Cornell University Press, Ithaca, 1993.

[14] S. Steinmo, "The End of Redistribution? International Pressures and Domestic Tax Policy Choices," Challenge, Vol. 37, No. 6, 1994, pp. 9-18.

[15] G. Brennan and J. Buchanan, "The Power to Tax: Analytical Foundations of a Fiscal Constitution," Cambridge University Press, Cambridge, 1980.

[16] D. Swank, "Global Capital, Political Institutions and Policy Change in Developed Welfare States," Cambridge University Press, Cambridge, 2002. http://dx.doi.org/10.1017/CBO9780511613371

[17] A. Razin and E. Sadka, "Efficient Investment Incentives in the Presence of Capital Flight," Journal of International Economics, Vol. 31, No. 1-2, 1991, pp. 171-181. http://dx.doi.org/10.1016/0022-1996(91)90062-B

[18] R. H. Gordon, "Can Capital Income Taxes Survive in Open Economies?" Journal of Finance, Vol. 47, No. 3, 1992, pp. 1159-1180. http://dx.doi.org/10.1111/j.1540-6261.1992.tb04009.x

[19] D. Rodrik, "Why Do More Open Economies Have Bigger Governments?" Journal of Political Economy, Vol. 106, 
No. 5, 1998, pp. 997-1032. http://dx.doi.org/10.1086/250038

[20] M. Keen and M. Marchand, "Fiscal Competition and the Pattern of Public Spending," Journal of Public Economics, Vol. 66, No. 1, 1997, pp. 33-53. http://dx.doi.org/10.1016/S0047-2727(97)00035-2

[21] P. Taylor-Gooby, "In Defence of Second-Best Theory: State, Class and Capital in Social Policy," Journal of Social Policy, Vol. 26, No. 2, 1997, pp. 171-192. http://dx.doi.org/10.1017/S0047279497004996

[22] D. Cameron, "The Expansion of the Public Economy: A Comparative Analysis," American Political Science Review, Vol. 72, No. 4, 1978, pp. 1243-1261. http://dx.doi.org/10.2307/1954537

[23] E. Huber, C. Ragin and J. Stephens, "Social Democracy, Christian Democracy, Constitutional Structure, and the Welfare State," American Journal of Sociology, Vol. 99, No. 3, 1993, pp. 711-749. http://dx.doi.org/10.1086/230321

[24] G. Garrett, "Capital Mobility, Trade, and the Domestic Politics of Economic Policy," In: R. Keohane and H. Milner, Eds., Internalization and Domestic Politics, Cambridge University Press, New York, 1996, pp. 79-107. http://dx.doi.org/10.1017/CBO9780511664168.005

[25] D. Quinn, "The Correlates of Change in International Financial Regulation," American Political Science Review, Vol. 91, No. 3, 1997, pp. 531-552. http://dx.doi.org/10.2307/2952073

[26] M. Hallerberg and S. Basinger, "Internationalization and Changes in Tax Policy in OECD Countries: The Importance of Domestic Veto Players," Comparative Political Studies, Vol. 31, No. 3, 1998, pp. 321-353. http://dx.doi.org/10.1177/0010414098031003003

[27] A. Dreher, "The Influence of Globalization on Taxes and Social Policy-An Empirical Analysis for OECD Countries," European Journal of Political Economy, Vol. 22, No. 1, 2006, pp. 179-201. http://dx.doi.org/10.1016/j.ejpoleco.2005.04.006

[28] D. Rodrik, "Has Globalization Gone Too Far," Institute for International Economics, Washington DC, 1997.

[29] D. Swank, "Funding the Welfare State: Globalization and the Taxation of Business in Advanced Market Economies," Political Studies, Vol. 46, No. 4, 1998, pp. 671692. http://dx.doi.org/10.1111/1467-9248.00161

[30] F. Heinemann, "Does Globalization Restrict Budgetary Autonomy: A Multidimensional Approach," ZEW Discussion Paper No 29, 1999.

[31] D. Swank and S. Steinmo, "The New Political Economy of Taxation in Advanced Capitalist Democracies," American Journal of Political Science, Vol. 46, No. 3, 2002, pp. 642-655. http://dx.doi.org/10.2307/3088405

[32] L. Bretschger and F. Hettich, "Globalisation, Capital Mobility and Tax Competition: Theory and Evidence for OECD Countries," European Journal of Political Economy, Vol. 18, No. 4, 2002, pp. 695-716. http://dx.doi.org/10.1016/S0176-2680(02)00115-5

[33] H. Winner, "Has Tax Competition Emerged in OECD Countries? Evidence from Panel Data," International Tax and Public Finance, Vol. 12, No. 5, 2005, pp. 667-687. http://dx.doi.org/10.1007/s10797-005-2915-0

[34] P. Schwartz, "Does Capital Mobility Reduce the Corporate-Labor Tax Ratio?" Public Choice, Vol. 130. No. 3-4, 2007, pp. 363-380. http://dx.doi.org/10.1007/s11127-006-9092-2

[35] W. Oates, "Fiscal Federalism," Harcourt Brace Jovanovich, New York, 1972.

[36] G. Garrett and J. Rodden, "Globalization and Fiscal Decentralization," In: M. Kahler and D. Lake, Eds., Governance in a Global Economy: Political Authority in Transition, Princeton University Press, Princeton, 2003, pp. 87-109.

[37] A. Alesina and E. Spolaore, "On the Number and Size of Nations," Quarterly Journal of Economics, Vol. 112, No. 4, 1997, pp. 1027-1056. http://dx.doi.org/10.1162/003355300555411

[38] A. Alesina and R. Wacziarg, "Openness, Country Size and Government," Journal of Public Economics, Vol. 69, No. 3, 1998, pp. 305-321.

http://dx.doi.org/10.1016/S0047-2727(98)00010-3

[39] P. Bolton and G. Roland, "The Breakup of Nations: A Political Economy Analysis," Quarterly Journal of Economics, Vol. 112, No. 4, 1997, pp. 1057-1090. http://dx.doi.org/10.1162/003355300555420

[40] P. Salmon, "Decentralisation as an Incentive Scheme," Oxford Review of Economic Policy, Vol. 3, No. 2, 1987, pp. 24-43. http://dx.doi.org/10.1093/oxrep/3.2.24

[41] L. R. De Mello Jr., "Globalization and Fiscal Federalism: Does Openness Constrain Subnational Budget Imbalances?" Public Budgeting and Finance, Vol. 25, No. 1, pp. $1-14$.

http://dx.doi.org/10.1111/j.0275-1100.2005.00351.x

[42] A. Alesina and R. Perotti, "Economic Risk and Political Risk in Fiscal Unions," The Economic Journal, Vol. 108, No. 449, 1998, pp. 989-1008. http://dx.doi.org/10.1111/1468-0297.00326

[43] Y. Y. Qian and B. R. Weingast, "Federalism as a Commitment to Rreserving Market Incentives," Journal of Economic Perspectives, Vol. 11, No. 4, 1997, pp. 83-92. http://dx.doi.org/10.1257/jep.11.4.83

[44] Y. Qian and G. Roland, "Federalism and the Soft Budget Constraint," The American Economic Review, Vol. 88, No. 5, 1998, pp. 1143-1162.

[45] M. Besfamille and B. Lockwood, "Bailouts in Federations: Is a Hard Budget Constraint Always Best?" International Economic Review, Vol. 49, No. 2, 2008, pp. 577593. http://dx.doi.org/10.1111/j.1468-2354.2008.00490.x

[46] C. M. Tiebout, "A Pure Theory of Local Government Expenditures," Journal of Political Economy, Vol. 64, No. 5, 1956, pp. 416-424. http://dx.doi.org/10.1086/257839

[47] G. Stigler, "The Tenable Range of Functions of Local Governments," Joint Economic Committee on Federal Expenditure Policy for Economic Growth and Stability, Washington DC, 1957.

[48] B. M. Mitnick, "The Political Economy of Regulation," Columbia University Press, New York, 1980.

[49] G. Garrett and J. Rodden, "Globalization and Decentrali- 
zation," Leitner Program in International and Comparative Political Economy, New Haven, 2000.

[50] J. Slemrod and S. Yitzhaki, "The Costs of Taxation and the Marginal Efficiency Cost of Funds," IMF Staff Papers, Vol. 43, 1996, pp. 172-198.

[51] A. Hülsemeyer, "Globalization and Institutional Adjustment-Federalism as an Obstacle?" Ashgate Publishing Limited, Farnham, 2004.

[52] P. G. Cerny, "Globalization and the Changing Logic of Collective Action," International Organization, Vol. 49, No. 4, 1995, pp. 595-625. http://dx.doi.org/10.1017/S0020818300028459

[53] B. S. Frey and R. Eichenberger, "FOCJ: Competitive Governments for Europe," International Review of Law and Economics, Vol. 16, No. 3, 1996, pp. 315-327. http://dx.doi.org/10.1016/0144-8188(96)00019-1

[54] D. Carey and J. Rabesona, "Tax Ratios on Labor and Capital Income, and on Consumption,” In: P. B. Sørensen, Ed., Measuring the Tax Burden on Capital and Labor, CESIFO Seminar Series, MIT Press, Cambridge, 2004.

[55] P. Liberati, "Trade Openness, Capital Openness and Government Size," Journal of Public Policy, Vol. 27, No. 2, 2007, pp. 215-247.

http://dx.doi.org/10.1017/S0143814X07000670
[56] K. P. Hagen, E. Norman and P. B. Sørensen, "Financing the Nordic Welfare States in an Integrating Europe," In: P. B. Sørensen, Ed., Tax Policy in the Nordic Countries, MacMillan, Houndmills, 1998, pp. 138-203.

[57] A. Pagan, "Econometric Issues in the Analysis of Regressions with Generated Regressors," International Economic Review, Vol. 25, No. 1, 1984, pp. 221-247. http://dx.doi.org/10.2307/2648877

[58] M. Arellano and S. Bond, "Some Tests of Specification for Panel Data: Monte Carlo Evidence and an Application to Employment Equations," Review of Economic Studies, Vol. 58, No. 2, 1991, pp. 277-297. http://dx.doi.org/10.2307/2297968

[59] M. Arellano and O. Bover, "Another Look at the Instrumental Variable Estimation of Error-Components Models," Journal of Econometrics, Vol. 68, No. 1, 1995, pp. 29-51. http://dx.doi.org/10.1016/0304-4076(94)01642-D

[60] R. Blundell and S. Bond, "Initial Conditions and Moment Restrictions in Dynamic Panel Data Models," Journal of Econometrics, Vol. 87, No. 1, 1998, pp. 115-143. http://dx.doi.org/10.1016/S0304-4076(98)00009-8

[61] D. Roodman, "How To Do Xtabond2: An Introduction to 'Difference' and 'System' GMM in Stata," Stata Journal, Vol. 9, No. 1, 2009, pp. 86-136. 


\section{Appendix}

Table A.1. Definition of variables and source.

\begin{tabular}{|c|c|c|}
\hline Main variables $^{(*)}$ & Description & Source \\
\hline taxKS_O & $\begin{array}{c}\text { Taxes on capital in the corporate sector (excluding taxes on } \\
\text { immovable properties-OECD definition) }\end{array}$ & Elaborations on OECD data \\
\hline$O S N \_L M$ & $\begin{array}{l}\text { Net operating surplus in the corporate sector-methodology developed by Mendoza et al. } \\
\text { (1994) and Carey and Rabesona (2002) }\end{array}$ & Elaborations on OECD data \\
\hline tKS_OMM2 & Effective tax rate on mobile capital (taxKS_O/OSN_LM) & Elaborations on OECD data \\
\hline$L A B$ & Taxes falling on labour (personal income taxes, social security contributions) & Elaborations on OECD data \\
\hline WAGE & Compensation of employees plus wage and payroll taxes & Elaborations on OECD data \\
\hline$t L \_O$ & Effective tax rate on labour ( $L A B / W A G E)$ & Elaborations on OECD data \\
\hline CONS & Sum of all taxes falling on consumption (VAT, excise taxes, etc.) & Elaborations on OECD data \\
\hline $\mathrm{FCH}$ & Final consumption expenditure by households & Elaborations on OECD data \\
\hline$t C \_E$ & Effective tax rate on consumption & Elaborations on OECD data \\
\hline IMCAP & Taxes falling on immobile capital & Elaborations on OECD data \\
\hline$t K K \_O M 2$ & Effective tax rate on immobile capital (IMCAP/OS) & Elaborations on OECD data \\
\hline tax_GDP & Tax burden (ratio between total tax revenue and GDP) & $\begin{array}{l}\text { Elaborations on OECD data } \\
\text { (both total tax revenue and GDP) }\end{array}$ \\
\hline OPEN & $\begin{array}{c}\text { Degree of economic integration (Numerator: exports + imports + inward FDI + outward FDI; } \\
\text { Denominator: GDP) }\end{array}$ & $\begin{array}{c}\text { Elaborations on OECD and } \\
\text { International } \\
\text { Financial Statistics data }\end{array}$ \\
\hline$O P E N^{2}$ & OPEN squared & \\
\hline ggov & General government spending over GDP & $\begin{array}{l}\text { OECD and Government } \\
\text { Financial Statistics, IMF }\end{array}$ \\
\hline loc & Local government spending over general government spending & $\begin{array}{l}\text { OECD and Government } \\
\text { Financial Statistics, IMF }\end{array}$ \\
\hline population & Population & OECD \\
\hline inc_us2 & Real income in $P P P \$$ & Penn World Tables \\
\hline
\end{tabular}

$(*)$ In the empirical section, some variables are used in first difference (indicated by $\Delta$ ) and lagged (indicated by ${ }_{t-1}$ ). 